\title{
Stability of Standard Electrolytic Conductivity Solutions in Glass Containers
}

\section{Rubina H. Shreiner}

National Institute of Standards and Technology,

Gaithersburg, MD 20899-8393

rubina.shreiner@nist.gov
The stability of solutions having an electrolytic conductivity, $\kappa$, of $5 \mu \mathrm{S} / \mathrm{cm}$ to $100000 \mu \mathrm{S} / \mathrm{cm}$ packaged in glass screwcap bottles, glass serum bottles, and glass ampoules was monitored for 1 year to 2 years. The conductivity was determined by measuring the ac resistance of the solution. Mass loss was also monitored for solutions packaged in bottles. The solutions were prepared using $\mathrm{KCl}$ in water $(\kappa \geq 100 \mu \mathrm{S} / \mathrm{cm})$ or $\mathrm{KCl}$ in $30 \%$ (by mass) n-propanol $70 \%$ (by mass) water $(\kappa \leq 15 \mu \mathrm{S} / \mathrm{cm})$. The conductivity changes were compared by packaging type and by nominal $\kappa$. The main causes of the $\kappa$ changes are evaporation (screw-cap bottles) and leaching (screw-cap bottles, serum bottles, and ampoules). Evaporation is determined from mass loss data; leaching occurs from the glass container with no change in mass. The choice of optimal packaging, which depends on the conductivity level, is the packaging in which $\kappa$ changes the least with time. Ampoules are the most suitable packaging for standards having nominal $\kappa$ values of $500 \mu \mathrm{S} / \mathrm{cm}$ to $100000 \mu \mathrm{S} / \mathrm{cm}$. Screw-cap bottles are most suitable for standards having a nominal $\kappa$ of $5 \mu \mathrm{S} / \mathrm{cm}$ to $100 \mu \mathrm{S} / \mathrm{cm}$.

Key words: conductivity; containers; packaging; potassium chloride; stability; standards.

Accepted: August 19, 2002

Available online: http://www.nist.gov/jres

\section{Introduction}

The measurement of electrolytic conductivity, $\kappa$, is used to monitor the ionic content of solutions (e.g., fruit juices, soft drinks, dialysis fluid, and natural waters) and the purity of water (e.g., drinking water, wastewater, process water). Many industries, including pharmaceutical, power, and health care, rely on electrolytic conductivity standards to calibrate electrolytic conductivity meters and cells. The availability of standards with accurate and stable $\kappa$ values is crucial to those industries.

The monitoring equipment is calibrated by measuring the resistance of a standard, $R_{\mathrm{c}}$, having a known conductivity, $\kappa_{\mathrm{c}}$, in a conductivity cell. The cell constant, $K_{\text {cell }}$, is then determined by Eq. (1),

$$
K_{\text {cell }}=\kappa_{\mathrm{c}} R_{\mathrm{c}} \text {. }
$$

The accuracy of this calibration, and the subsequent measurements, is determined by the accuracy of the standard. The conductivity of a solution, $\kappa_{\mathrm{s}}$, can then be determined by Eq. (2),

$$
\kappa_{\mathrm{s}}=K_{\text {cell }} / R_{\mathrm{s}}
$$

where $R_{\mathrm{S}}$ is the resistance of the solution measured in a cell with a known $K_{\text {cell }}$.

A practical consideration in the accuracy of electrolytic conductivity standards, as with all standards, is their stability, or change in certified value versus time. Although there is a large body of data with regard to standard electrolytic conductivity solutions, e.g., Refs. [1-10], data regarding the long-term stability of the standard solutions are lacking. Obviously, any change from 
the certified value will compromise the accuracy of the standard at the time of use and must be considered in establishing both the uncertainty in $\kappa$ and the expiration date of the reference material. This paper reports the change of $\kappa$ in solutions packaged in a variety of container types observed for several years.

NIST prepares and certifies electrolytic conductivity standards in the range of $5 \mu \mathrm{S} / \mathrm{cm}$ to $100000 \mu \mathrm{S} / \mathrm{cm}$ as SRMs (Standard Reference Materials) 3190 to 3199. The certificates for these SRMs typically expire in 1 year to 2 years because of the difficulties in maintaining their long-term stability. Stability is one of the factors in the certified uncertainties, which vary from $0.07 \%$ to $4 \%$ in the most recent certifications of the highest and lowest conductivity standards in this group, respectively. Neglecting the contribution of instability, the certified uncertainties of these SRMs would be in the range of $0.07 \%$ to $2 \%$ (Table 1). The goal of this study is to achieve an uncertainty close to the target values for each SRM listed in Table 1.

All of the containers in this study were glass. Evaporation and leaching are the two main problems with glass containers. Evaporation occurs through the space between the cap and the bottle, causing a simultaneous mass loss and $\kappa$ increase of the solution. The $\kappa$ increase would be approximately proportional to mass loss from evaporation. A $\kappa$ increase of the solution with no mass loss would be indicative of an increase in the ionic strength from leaching. Three types of packaging have been tested: glass screw-cap bottles, glass serum bottles, and glass ampoules. The stability of solutions ranging in conductivity from $5 \mu \mathrm{S} / \mathrm{cm}$ to $100000 \mu \mathrm{S} / \mathrm{cm}$ was monitored. The causes of instability and the choice of the best packaging type are discussed.

\section{Experimental}

\subsection{Solution Preparation and Packaging}

Containers that were readily available to users and producers of conductivity standards were chosen for this study. Screw-cap bottles, serum bottles, and ampoules were purchased commercially and were each made of borosilicate glass $[11,12]^{1}$. The $500 \mathrm{~mL}$ screw-cap bottles had polypropylene plug seal caps. The $100 \mathrm{~mL}$ serum bottles had aluminum caps, which were lined with Teflon ${ }^{\circledR}$ faced gray butyl septa. The $50 \mathrm{~mL}$ ampoules were sealed in a natural gas $/ \mathrm{O}_{2}$ flame. The glass composition of the screw-cap bottles and the ampoules was significantly different from the glass composition of the serum bottles (Table 2). Thus, three parameters differed among the bottles studied: closure type, glass type, and volume to surface area ratio.

Solutions were prepared using deionized water $(\kappa<0.06 \mu \mathrm{S} / \mathrm{cm}$ at delivery) and potassium chloride (reagent grade). Mixed aqueous-nonaqueous solutions (5 $\mu \mathrm{S} / \mathrm{cm}$ and $15 \mu \mathrm{S} / \mathrm{cm}$, only) were prepared using n-propanol (assayed by the manufacturer at $100 \%$ ) and deionized water. A total of fifteen solutions were separately prepared and monitored. The solutions' nominal conductivities, the packaging types, and the approximate masses of $\mathrm{KCl}$ are displayed in Table 1. The solutions were thoroughly mixed and homogenized. All solutions were equilibrated with atmospheric $\mathrm{CO}_{2}$ prior to packaging.

Each screw-cap bottle was filled with $\approx 500 \mathrm{~mL}$ of solution and immediately capped. The cap-bottle juncture of the screw-cap bottles used for the $100 \mu \mathrm{S} / \mathrm{cm}$ and $1000 \mu \mathrm{S} / \mathrm{cm}$ solutions were wrapped in Parafilm (44 d

Table 1. Solution preparation

\begin{tabular}{|c|c|c|c|c|c|}
\hline \multirow[b]{2}{*}{$\begin{array}{l}\text { Nominal } \\
\kappa /(\mu S / c m)\end{array}$} & \multicolumn{5}{|c|}{ Packaging type } \\
\hline & $\begin{array}{c}\text { Target } \\
\text { uncertainty } /(\%)\end{array}$ & $\begin{array}{c}\text { Screw-cap } \\
\text { bottles }\end{array}$ & $\begin{array}{l}\text { Serum } \\
\text { bottles }\end{array}$ & Ampoules & $\begin{array}{c}\text { Approximate } m_{\mathrm{KCl}} \\
\text { per } \mathrm{kg} \text { of solution } /(\mathrm{g})\end{array}$ \\
\hline 5 & 2 & $\checkmark$ & & $\checkmark$ & 0.0053 \\
\hline 15 & 0.7 & $\checkmark$ & $\checkmark$ & $\checkmark$ & 0.017 \\
\hline 100 & 0.2 & $\checkmark$ & $\nu$ & $\checkmark$ & 0.050 \\
\hline 500 & 0.07 & & $\checkmark$ & $v$ & 0.25 \\
\hline 1000 & 0.07 & $\checkmark$ & $\checkmark$ & $\checkmark$ & 0.53 \\
\hline 100000 & 0.07 & & $\checkmark$ & $\checkmark$ & 63 \\
\hline
\end{tabular}

${ }^{\text {a }}$ Relative expanded uncertainty at the $95 \%$ confidence interval.

\footnotetext{
${ }^{1}$ Certain commercial equipment, instruments, or materials are identified in this paper to foster understanding. Such identification does not imply recommendation or endorsement by the National Institute of Standards and Technology nor does it imply that the materials or equipment identified are necessarily the best available for the purpose.
} 
Table 2. Compositions of glass types used for each container

\begin{tabular}{|c|c|c|c|}
\hline \multirow[b]{2}{*}{ Component } & \multicolumn{3}{|c|}{$\%$ Composition as provided by the manufacturer } \\
\hline & Screw-capped bottles ${ }^{\mathrm{a}}$ & Serum bottles $^{\mathrm{b}}$ & Ampoules ${ }^{\mathrm{b}}$ \\
\hline $\mathrm{SiO}_{2}$ & 80.6 & 69.5 & 81 \\
\hline $\mathrm{B}_{2} \mathrm{O}_{3}$ & 13.0 & 10.4 & 13 \\
\hline $\mathrm{Al}_{2} \mathrm{O}_{3}$ & 2.3 & 5.5 & 2 \\
\hline $\mathrm{Na}_{2} \mathrm{O}+\mathrm{K}_{2} \mathrm{O}$ & 4.1 & 10.0 & 4.2 \\
\hline $\mathrm{CaO}+\mathrm{MgO}$ & & 1.4 & $<0.02$ \\
\hline $\mathrm{BaO}$ & & 2.5 & $<0.1$ \\
\hline $\mathrm{ZnO}$ & & 0.5 & \\
\hline Minors & & & \\
\hline$\left(\mathrm{F}, \mathrm{MnO}_{2}, \mathrm{Fe}_{2} \mathrm{O}_{3}, \mathrm{Li}_{2} \mathrm{O}, \mathrm{CeO}_{2}\right)$ & & 0.3 & \\
\hline
\end{tabular}

${ }^{a}$ See Ref. [11].

${ }^{\mathrm{b}}$ See Ref. [12].

after bottling for the $1000 \mu \mathrm{S} / \mathrm{cm}$ solution; the day of bottling for the $100 \mu \mathrm{S} / \mathrm{cm}$ solution). Each serum bottle was filled with $\approx 100 \mathrm{~mL}$ of solution and immediately capped. The mass loss of each screw-cap bottle and serum bottle was monitored. Each ampoule was filled with $\approx 50 \mathrm{~mL}$ of solution (air head-space) and immediately sealed in a natural gas $/ \mathrm{O}_{2}$ flame. All of the containers for a given solution were filled and capped (or sealed) in 1 day. The mass loss of the $1000 \mu \mathrm{S} / \mathrm{cm}$ solution packaged in ampoules was monitored for the first $23 \mathrm{~d}$. Ampoules that lost mass were discarded, since mass loss indicated a pinhole. For the other solutions packaged in ampoules, a vacuum was pulled on the seal of each ampoule. If there were a hole in the seal of the ampoule, liquid would be visible in the tubing. Any ampoule in which liquid was observed in the tubing was discarded.

All of the containers were stored on shelves and/or in boxes in rooms with an air temperature of $20^{\circ} \mathrm{C} \pm 5{ }^{\circ} \mathrm{C}$.

Over the 2 year study, random units were selected for measurement and each unit was only used once. A "unit" refers to the set of containers (1 screw-cap bottle, 2 to 3 serum bottles, or 5 to 6 ampoules) needed to obtain a sufficient quantity of solution to perform one measurement (including necessary preliminary rinses of the cell). Three to seven units were measured at each time period and the mean of these measurements was taken as the value of the solution at that time.

\subsection{Equipment and Measurement Method}

The equipment used for the measurements has been previously described [13]. An ac measurement technique was used to determine the conductivity of each unit at $25.000{ }^{\circ} \mathrm{C} \pm 0.003{ }^{\circ} \mathrm{C}$ [13]. The conductivity cells were calibrated with primary standards $[4,7,13]$. The cell was rinsed 4 to 5 times and filled with solution from the same unit. The ac resistance was measured at
$1 \mathrm{kHz}\left(R_{1 \mathrm{kHz}}\right)$ and $2 \mathrm{kHz}\left(R_{2 \mathrm{kHz}}\right)$ and the resistance was extrapolated linearly to infinite frequency [14]. The lead resistance was subtracted from the extrapolated resistance to obtain the resistance of the solution, $R$. The conductivity, $\kappa$, of the solution was calculated by Eq. (2).

\section{Results and Discussion}

The results of this study were obtained by grouping the data according to the type of container and, separately, by the $\kappa$ value. Thus, the following discussion is organized accordingly.

\subsection{Comparison by Container}

The mean conductivities determined at each time period are shown in Fig. 1 and the standard deviations are shown in Tables 3-5. The relative change in $\kappa$ with time increases with decreasing $\kappa$ for all three packaging types. The conductivity data for each solution illustrates consistent batch change and not the change of an individual unit, since each unit was measured only once.

A $\kappa$ increase (Fig. 1A) and mass loss, generally $<0.5 \%$, were observed for solutions packaged in the screw-cap bottles. The mass loss is caused by evaporation. Upon closer inspection of the bottles, it was noticed that the caps had loosened and needed to be retightened. Previous to these experiments, screw-cap bottles occasionally leaked during shipment, further supporting the hypothesis of an imperfect cap. The relative change in mass due to evaporation is approximately equal to the relative $\kappa$ change if evaporation is the only cause of the solution's instability. For the $1000 \mu \mathrm{S} / \mathrm{cm}$ solution, the entire relative $\kappa$ change $(0.25 \%)$ may be explained by mass loss. However, the relative $\kappa$ changes for the 
Table 3. Standard deviation, $s^{\mathrm{a}}$, at time, $t^{\mathrm{b}}$, for solutions packaged in screw-capped bottles

\begin{tabular}{|c|c|c|c|c|c|c|c|}
\hline \multicolumn{2}{|c|}{$5 \mu \mathrm{S} / \mathrm{cm}$} & \multicolumn{2}{|c|}{$15 \mu \mathrm{S} / \mathrm{cm}$} & \multicolumn{2}{|c|}{$10 \mu \mathrm{S} / \mathrm{cm}$} & \multicolumn{2}{|c|}{$1000 \mu \mathrm{S} / \mathrm{cm}$} \\
\hline$t$ & $s$ & $t$ & $s$ & $t$ & $s$ & $t$ & $s$ \\
\hline 0 & 0.10 & 0 & 0.02 & 0 & 0.03 & 0 & 0.01 \\
\hline 0.5 & 0.06 & 1.2 & 0.09 & 0.5 & 0.02 & 0.5 & 0.01 \\
\hline 5.7 & 1.4 & 19.5 & 0.65 & 5.7 & 0.20 & 3.0 & 0.03 \\
\hline \multirow[t]{5}{*}{12.4} & 0.16 & & & 9.9 & 0.24 & 6.8 & 0.05 \\
\hline & & & & 12.4 & 0.09 & 12.6 & 0.07 \\
\hline & & & & & & 14.9 & 0.04 \\
\hline & & & & & & 18.8 & 0.10 \\
\hline & & & & & & 24.6 & 0.11 \\
\hline
\end{tabular}

${ }^{\text {a }}$ Standard deviation has units of $\%$ relative.

${ }^{\mathrm{b}}$ Time has units of months.

Table 4. Standard deviation, $s^{\mathrm{a}}$, at time, $t^{\mathrm{b}}$, for solutions packaged in serum bottles

\begin{tabular}{|c|c|c|c|c|c|c|c|c|c|}
\hline \multicolumn{2}{|c|}{$15 \mu \mathrm{S} / \mathrm{cm}$} & \multicolumn{2}{|c|}{$100 \mu \mathrm{S} / \mathrm{cm}$} & \multicolumn{2}{|c|}{$500 \mu \mathrm{S} / \mathrm{cm}$} & \multicolumn{2}{|c|}{$1000 \mu \mathrm{S} / \mathrm{cm}$} & \multicolumn{2}{|c|}{$100000 \mu \mathrm{S} / \mathrm{cm}$} \\
\hline$t$ & $s$ & $t$ & $s$ & $t$ & $s$ & $t$ & $s$ & $t$ & $s$ \\
\hline 0 & 0.04 & 0 & 0.25 & 0 & 0.03 & 0 & 0.00 & 0 & 0.01 \\
\hline 1.0 & 0.59 & 9.1 & 2.7 & 4.4 & 0.02 & 0.6 & 0.01 & 3.6 & 0.00 \\
\hline 2.7 & 2.3 & 12.5 & 1.2 & 8.4 & 0.51 & 3.9 & 0.01 & 8.1 & 0.01 \\
\hline 6.4 & 3.0 & 18.6 & 11 & 12.6 & 1.3 & 6.0 & 0.13 & 12.6 & 0.01 \\
\hline 9.9 & 4.5 & & & 15.6 & 2.0 & 12.1 & 0.27 & 18.0 & 0.04 \\
\hline 13.1 & 4.6 & & & 20.5 & 2.9 & 14.0 & 0.76 & 24.2 & 0.01 \\
\hline 18.1 & 6.1 & & & 24.0 & 3.3 & & & & \\
\hline 25.0 & 6.1 & & & & & & & & \\
\hline 30.1 & 2.6 & & & & & & & & \\
\hline
\end{tabular}

${ }^{\text {a }}$ Standard deviation has units of $\%$ relative.

${ }^{\mathrm{b}}$ Time has units of months.

Table 5. Standard deviation, $s^{\mathrm{a}}$, at time, $t^{\mathrm{b}}$, for solutions packaged in ampoules

\begin{tabular}{|c|c|c|c|c|c|c|c|c|c|c|c|}
\hline \multicolumn{2}{|c|}{$5 \mu \mathrm{S} / \mathrm{cm}$} & \multicolumn{2}{|c|}{$15 \mu \mathrm{S} / \mathrm{cm}$} & \multicolumn{2}{|c|}{$100 \mu \mathrm{S} / \mathrm{cm}$} & \multicolumn{2}{|c|}{$500 \mu \mathrm{S} / \mathrm{cm}$} & \multicolumn{2}{|c|}{$1000 \mu \mathrm{S} / \mathrm{cm}$} & \multicolumn{2}{|c|}{$100000 \mu \mathrm{S} / \mathrm{cm}$} \\
\hline$t$ & $s$ & $t$ & $s$ & $t$ & $s$ & $t$ & $s$ & $t$ & $s$ & $t$ & $s$ \\
\hline 0.0 & 0.43 & 0.0 & 0.21 & 0.0 & 0.06 & 0.0 & 0.02 & 0.0 & 0.01 & 0.0 & 0.01 \\
\hline 4.1 & 0.49 & 4.7 & 0.27 & 4.0 & 0.17 & 1.2 & 0.02 & 1.1 & 0.01 & 3.8 & 0.01 \\
\hline 7.7 & 0.99 & 8.1 & 0.54 & 8.3 & 0.17 & 3.2 & 0.02 & 6.0 & 0.01 & 7.9 & 0.01 \\
\hline 11.8 & 1.1 & 12.2 & 0.33 & 12.0 & 0.18 & 6.1 & 0.03 & 12.0 & 0.02 & 12.0 & 0.01 \\
\hline 16.0 & 0.67 & 16.1 & 0.51 & 15.9 & 0.13 & 12.0 & 0.04 & 17.8 & 0.02 & & \\
\hline 19.9 & 1.1 & 19.9 & 0.40 & 20.1 & 0.10 & & & 25.1 & 0.05 & & \\
\hline
\end{tabular}

${ }^{\mathrm{a}}$ Standard deviation has units of $\%$ relative.

${ }^{\mathrm{b}}$ Time has units of months.

$5 \mu \mathrm{S} / \mathrm{cm}(\approx 5.5 \%), 15 \mu \mathrm{S} / \mathrm{cm}(\approx 2.4 \%)$ and $100 \mu \mathrm{S} / \mathrm{cm}$ $(\approx 0.7 \%)$ solutions were significantly greater than the relative mass loss. The disparity between the $\kappa$ data and the mass loss data indicates that leaching from the glass, yielding ions, especially sodium [15-17], to the solution, must also be occurring. Both leaching and evaporation contributed to the observed $\kappa$ change in the $5 \mu \mathrm{S} / \mathrm{cm}$, $15 \mu \mathrm{S} / \mathrm{cm}$, and $100 \mu \mathrm{S} / \mathrm{cm}$ solutions.

A $\kappa$ increase for solutions with $\kappa \leq 1000 \mu \mathrm{S} / \mathrm{cm}$ (Fig. 1B) and mass loss, generally $<0.07 \%$, were observed for the serum bottles. This mass loss is caused by evaporation. The conductivity of the $100000 \mu \mathrm{S} / \mathrm{cm}$ solution did not change significantly during the time it was monitored. However, the relative $\kappa$ change for the $15 \mu \mathrm{S} / \mathrm{cm}(\approx 18 \%), 100 \mu \mathrm{S} / \mathrm{cm}(\approx 11 \%), 500 \mu \mathrm{S} / \mathrm{cm}$ $(\approx 8 \%)$, and $1000 \mu \mathrm{S} / \mathrm{cm}(\approx 1 \%)$ solutions was significantly larger than the observed mass loss. The disparity between the relative $\kappa$ change and relative mass loss indicates that leaching from the glass is occurring. Leaching is the major cause of $\kappa$ change for these solutions. The serum bottles have a 1.6 times smaller volume to surface area ratio than the screw-cap bottles. 

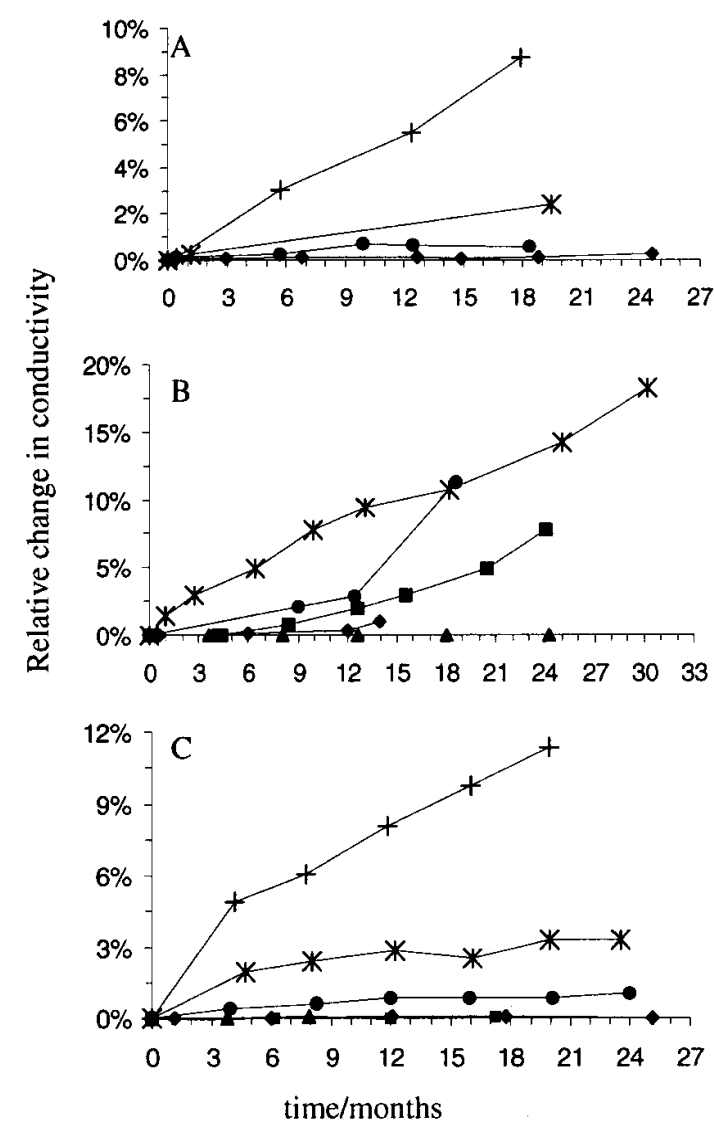

Fig. 1. Solution instability by packaging type. A-screw-capped bottles; B-serum bottles; C-ampoules; $+5 \mu \mathrm{S} / \mathrm{cm}$, * $15 \mu \mathrm{S} / \mathrm{cm}$, - $100 \mu \mathrm{S} / \mathrm{cm}, \mathbb{\square} 500 \mu \mathrm{S} / \mathrm{cm}, \downarrow 1000 \mu \mathrm{S} / \mathrm{cm}, \boldsymbol{\Delta} 100000 \mu \mathrm{S} / \mathrm{cm}$. The standard deviation for each point is given in Tables 3 to 5 .

Also, the glass used for the serum bottles has a higher concentration of leachable species than the glass used for the screw-cap bottles or the ampoules (Table 2). Therefore, leaching from the serum bottles would result in a higher concentration of ions in the solution and would increase the conductivity of the solution to a greater extent than in the screw-cap bottles, as observed.

A $\kappa$ increase was observed for solutions with $\kappa \leq 100 \mu \mathrm{S} / \mathrm{cm}$ (Fig. 1C) packaged in ampoules, but a mass loss was not observed. Evaporation was eliminated. The conductivity increases that were observed for the $5 \mu \mathrm{S} / \mathrm{cm}(\approx 11 \%), 15 \mu \mathrm{S} / \mathrm{cm}(\approx 3 \%)$, and $100 \mu \mathrm{S} / \mathrm{cm}(\approx 0.9 \%)$ solutions are due to leaching. However, leaching did not affect the conductivities of the $500 \mu \mathrm{S} / \mathrm{cm}, 1000 \mu \mathrm{S} / \mathrm{cm}$, and $100000 \mu \mathrm{S} / \mathrm{cm}$ solutions, which did not change significantly. Ampoules have a 1.6 times smaller volume to surface area ratio than the serum bottles. However, the concentration of leachable species in the glass is less in the case of ampoules than with serum bottles (Table 2). Therefore, it is not surprising that the leaching effect observed with ampoules is less than the leaching effect observed with serum bottles.

The scatter in $\kappa$ of the 3 to 7 units measured at each time period increased with time for solutions that had increases in mean $\kappa$ with time. The increase in standard deviation with increasing time, shown in Tables 3 to 5 , is indicative of an increase in scatter. Variations in evaporation and/or leaching would cause the observed bottleto-bottle or ampoule-to-ampoule differences. The effects of evaporation or leaching are slightly different for each container and are expected to increase with time. For some solutions, the scatter initially increased with time then appeared to level off. A bottle-to-bottle or ampoule-to-ampoule effect was observed for solutions that had no conductivity change with time, but no significant increase in the scatter with time was observed.

\subsection{Comparison by Conductivity}

The data are reorganized according to levels of conductivity in Figs. 2 and 3. The $5 \mu \mathrm{S} / \mathrm{cm}$ solution was most stable when packaged in screw-cap bottles (Fig. $2 \mathrm{~A})$. The $15 \mu \mathrm{S} / \mathrm{cm}$ solution was similarly stable in screw-cap bottles and ampoules (Fig. 2B). The

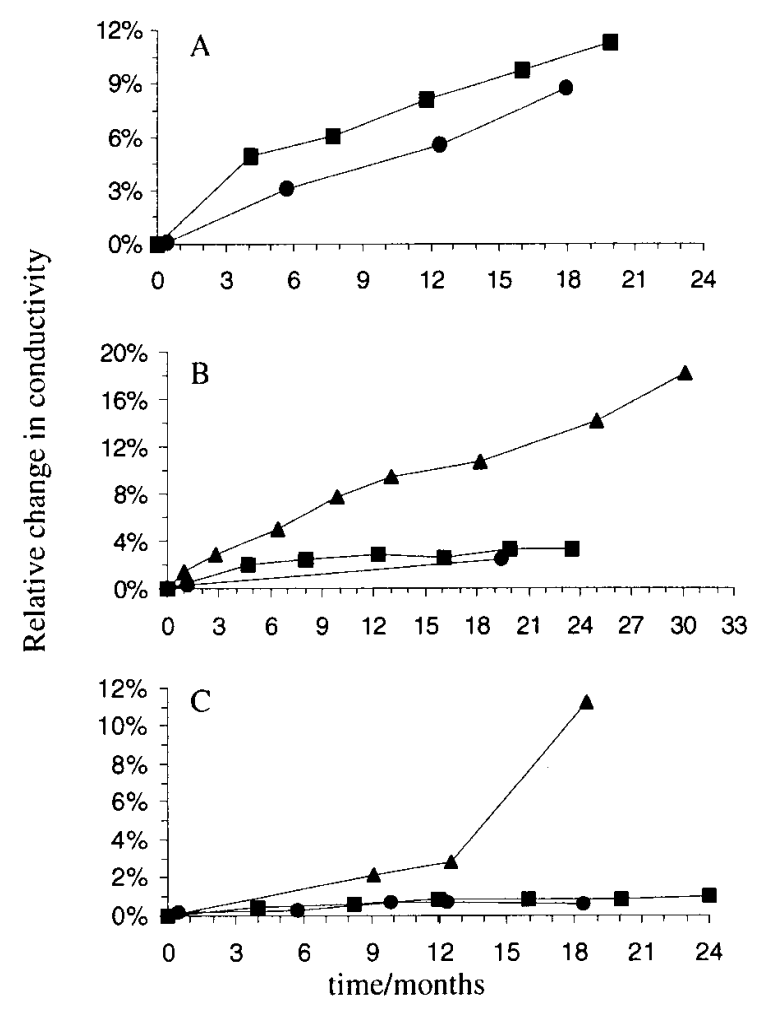

Fig. 2. Change in conductivity of the $5 \mu \mathrm{S} / \mathrm{cm}, 15 \mu \mathrm{S} / \mathrm{cm}$, and $100 \mu \mathrm{S} / \mathrm{cm}$ solutions. A $-5 \mu \mathrm{S} / \mathrm{cm}$; B $-15 \mu \mathrm{S} / \mathrm{cm}$; C $-100 \mu \mathrm{S} / \mathrm{cm}$; - screw-capped bottles, $\boldsymbol{\Lambda}$ serum bottles, $\boldsymbol{\square}$ ampoules. The standard deviation for each point is given in Tables 3 to 5 . 


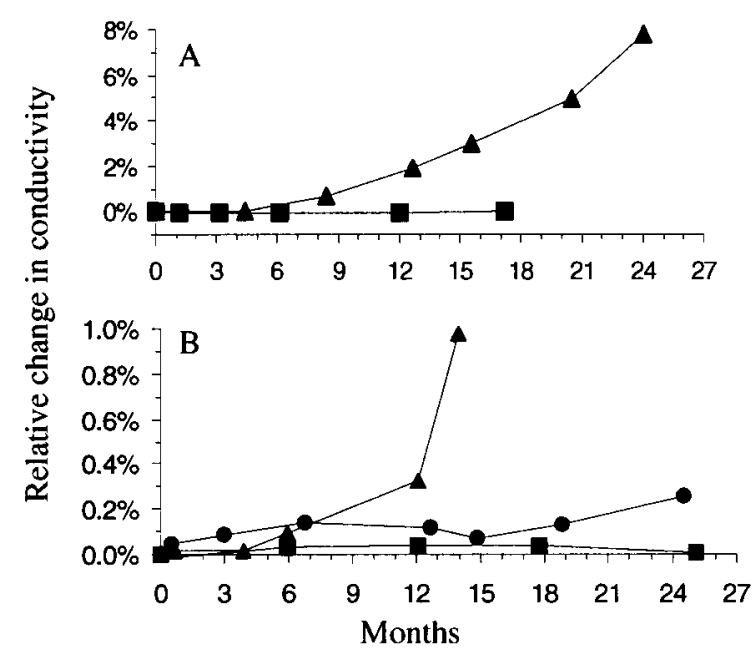

Fig. 3. Change in conductivity of the $500 \mu \mathrm{S} / \mathrm{cm}$ and $1000 \mu \mathrm{S} / \mathrm{cm}$ solutions. A-500 $\mu \mathrm{S} / \mathrm{cm}$; B-1000 $\mu \mathrm{S} / \mathrm{cm}$; screw-capped bottles, $\boldsymbol{\Delta}$ serum bottles, $\mathbf{a}$ ampoules. The standard deviation for each point is given in Tables 3 to 5 .

$100 \mu \mathrm{S} / \mathrm{cm}$ solution was similarly stable in screw-cap bottles and ampoules (Fig. 2C). The $500 \mu \mathrm{S} / \mathrm{cm}$ and $1000 \mu \mathrm{S} / \mathrm{cm}$ solutions were most stable in ampoules (Fig. 3). The $100000 \mu \mathrm{S} / \mathrm{cm}$ solution had no measurable change in conductivity in either the serum bottles or the ampoules and is not included in the graphs.

\section{Conclusions}

The experiment indicates that leaching, which is dependent upon glass type, is the dominant source of instability for the low-conductivity solutions $(\kappa \leq 100 \mu \mathrm{S} / \mathrm{cm})$. The dominant source of instability for the high-conductivity solutions $(\kappa \geq 500 \mu \mathrm{S} / \mathrm{cm})$ may be either leaching (serum bottles) or evaporation (screw-cap bottles), depending on container type and size. Both leaching and evaporation increase proportionately with time of storage, up to the 2 years studied here.

The best package for the highest accuracy standards is the one in which the solution has either no change in $\kappa$ with time or a small change in $\kappa$ that does not significantly affect the target uncertainty (Table 1). The highconductivity solutions should be packaged in containers in which there was no change in $\kappa$ with time: ampoules ( $\geq 500 \mu \mathrm{S} / \mathrm{cm}$ ) or serum bottles $(100000 \mu \mathrm{S} / \mathrm{cm}$, only). The low-conductivity solutions had large changes in $\kappa$ with time $(>0.7 \%)$ when packaged in any container. Thus, they can not be stored for any length of time for the highest accuracy work. If long-term storage is necessary for less accurate work, the low-conductivity standards should be packaged in containers that showed the smallest change in $\kappa$ with time: screw-cap bottles ( $\leq 100 \mu \mathrm{S} / \mathrm{cm})$ or ampoules $(15 \mu \mathrm{S} / \mathrm{cm}$ and $100 \mu \mathrm{S} / \mathrm{cm}$, only).

Solution packaged in serum bottles was much less stable than the other packaging types tested. The instability of solutions packaged in serum bottles has also been found to be somewhat different from batch-tobatch at the same nominal conductivity.

The screw-cap bottles and ampoules both work equally well for some solutions. In these cases, convenience and cost should also be considered to determine which package is the best choice. The bottles are much more convenient in terms of filling, capping, and opening to make a measurement. Although the bottles are easy to ship, they can leak. The ampoules require much more time to fill and seal for the same amount of solution (10 times more ampoules than bottles would be needed). Although ampoules are easy to open to make a measurement, it may be necessary to open as many as 6 to obtain sufficient solution to make one measurement. The ampoules also cost more in terms of (1) original cost of the ampoule, (2) labor, due to the amount of time required for ampouling, and (3) shipping, due to their fragility. Therefore, in cases where the given solution packaged in ampoules or screw-cap bottles will have the same stability (e.g., $15 \mu \mathrm{S} / \mathrm{cm}$ and $100 \mu \mathrm{S} / \mathrm{cm}$ for shortterm and long-term storage; $500 \mu \mathrm{S} / \mathrm{cm}$ for short-term storage), screw-cap bottles are the best choice.

Considering all of the applicable factors, cost, convenience, and stability (as discussed previously), the following recommendations are made for packaging of electrolytic conductivity standards: $5 \mu \mathrm{S} / \mathrm{cm}$ to $100 \mu \mathrm{S} / \mathrm{cm}$ in screw-cap bottles and $500 \mu \mathrm{S} / \mathrm{cm}$ to $100000 \mu \mathrm{S} / \mathrm{cm}$ in ampoules. For conductivity values between $100 \mu \mathrm{S} / \mathrm{cm}$ and $500 \mu \mathrm{S} / \mathrm{cm}$, the packaging type should be tested. The optimal point to switch from ampoules to screw-cap bottles occurs at a $\kappa$ value between $100 \mu \mathrm{S} / \mathrm{cm}$ and $500 \mu \mathrm{S} / \mathrm{cm}$ but its exact value was not more thoroughly examined.

When examining other types of glass containers, the conductivity and mass change of the solution in the container should be examined to assess the stability of the solution in the given packaging type. The container should be air tight to eliminate evaporation. The glass used for the container should have the lowest possible concentration of leachable species, especially sodium, to minimize the effects of leaching. Leaching from glass containers can also be minimized by using a container which has a relatively large volume to surface area ratio.

Plastic containers are presently being studied. The results will be presented in future work. 


\section{Acknowledgments}

The author would like to thank Kenneth Pratt and Thomas Vetter for their interest in this work and helpful discussions.

\section{References}

[1] H. C. Parker and E. W. Parker, Calibration of Cells for Conductance Measurements. III. Absolute Measurements on the Specific Conductance of Certain Potassium Chloride Solutions, J. Am. Chem. Soc. 46, 312-335 (1924).

[2] G. Jones and B. C. Bradshaw, The Measurement of the Conductance of Electrolytes. V. A Redetermination of the Conductance of Standard Potassium Chloride Solutions in Absolute Units. J. Am. Chem. Soc. 55, 1780-1800 (1933).

[3] Y. C. Wu, W. F. Koch, W. J. Hamer, and R. L. Kay, Review of Electrolytic Conductance Standards, J. Solution Chem. 16, 985997 (1987); 19, 1053-1054 (1990).

[4] Standard Solutions Reproducing the Conductivity of Electrolytes, International Recommendation No. 56, Organisation Internationale de Métrologie Légale (OIML), June 1980 (Bureau International de Métrologie Légale, Paris, 1981).

[5] Y. C. Wu, K. W. Pratt, and W. F. Koch, Determination of the Absolute Specific Conductance of Primary Standard KCl Solutions, J. Solution Chem. 18, 515-528 (1989).

[6] Y. C. Wu, W. F. Koch, and K. W. Pratt, Proposed New Electrolytic Conductivity Primary Standards for $\mathrm{KCl}$ Solutions, J. Res. Natl. Inst. Stand. Technol. 96, 191-201 (1991).

[7] K. W. Pratt, W. F. Koch, Y. C. Wu, and P. A. Berezansky, Molality-Based Primary Standards of Electrolytic Conductivity (IUPAC Technical Report), Pure Appl. Chem. 73, 1783-1793 (2001).

[8] Y. C. Wu, W. F. Koch, D. Feng, L. A. Holland, E. Juhasz, E. Arvay, and A. Tomek, A dc Method for the Absolute Determination of Conductivities of the Primary Standard $\mathrm{KCl}$ Solutions from $0{ }^{\circ} \mathrm{C}$ to $50{ }^{\circ} \mathrm{C}$, J. Res. Natl. Inst. Stand. Technol. 99, 241246 (1994).

[9] Y. C. Wu and P. Berezansky, Low Electrolytic Conductivity Standards, J. Res. Natl. Inst. Stand. Technol. 100, 521-527 (1995).

[10] Y. C. Wu and W. F. Koch, Absolute Determination of Electrolytic Conductivity for Primary Standard $\mathrm{KCl}$ Solutions from 0 to $50{ }^{\circ} \mathrm{C}$, J. Solution Chem. 20, 391-401 (1991).

[11] Corning, Inc. (2001) www.corning.com.

[12] Wheaton Science Productions (2001) www.wheatonsci.com.

[13] R. H. Jameel, Y. C. Wu, and K. W. Pratt, Primary Standards and Standard Reference Materials for Electrolytic Conductivity, Natl. Inst. Stand. Technol. Spec. Publ. 260-142, Washington, US Government Printing Office, 2000, 46 pp.

[14] R. A. Robinson and R. H. Stokes, Electrolyte Solutions, 3rd Edition, Butterworths, London (1959).

[15] A. C. Bevilacqua, Calibration and Performance of a Conductivity System to Meet USP 23, Ultrapure Water (Nov. 1996) pp. 25-34.

[16] R. H. Doremus, Glass Science, John Wiley \& Sons, New York (1973) pp. 242-248.

[17] A. Paul, Chemistry of Glasses, Chapman and Hall, New York (1990) pp. 180-184.
About the author: Rubina H. Shreiner is a chemist in the Analytical Chemistry Division of the NIST Chemical Sciences and Technology Laboratory. The National Institute of Standards and Technology is an agency of the Technology Administration, U.S. Department of Commerce. 